\title{
A globalização e seus reflexos so- bre os trabalhadores "estáveis": petroleiros da Fafen/Petrobrás ${ }^{1}$
}

FREDERICO IISBÔA ROMÃO*

\section{Introdução}

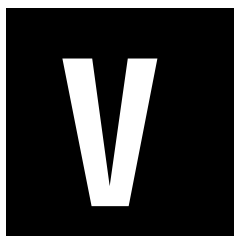

ivemos momentos de transição em todos os sentidos da vida humana. A globalização nos tem feito partícipes de mudanças em velocidades anteriormente inimagináveis, obrigado-nos a navegar em mares nunca dantes navegados. 0 avanço possibilitado pelas novas tecnologias penetra de forma acachapante em todos os lares e organizações. 0 mundo, que antes era de mil e uma noites, avança para milhões de giga bytes de possibilidades, as comunicações e o uso da internet revolucionam, encurtando distâncias. 0 nosso mundo ficou menor, o homem que saiu do campo para a cidade, hoje retorna à aldeia, a aldeia global.

O correm transformações fantásticas no campo da hard science ou da human science, é fase de revolução (Khun, 1994). A instabilidade técnica, e seu uso por parte dos setores hegemônicos, leva aos (des)ajustes globais (Tavares, 1996). Cientistas sociais defendem o repensar radical do fazer ciência, muitos dos nosso sobjetos esvaíram-se antes de os termos dissecado: ou reformulamos os campos e instrumentos de ação, ou as ciências sociais perderão relevância.

É uma era de incertezas. As metáforas se multiplicam: fábrica global, desterritorialização, fim da história, fim dasclasses, fim do emprego (lanni, 1999), refletindo as interrogações e a incapacidade de se apreender o momento.

\footnotetext{
1 Trabalho apresentado pelo autor no XXIV Encontro Anual da AN PO CS/ GT Sindicalismo e Política Petrópolis - RJ 23 a 27 de outubro de 2000, contou com a colaboração na coleta de dados, do graduando em Ciências Sociais pela U FS, Florival J.S. Filho.

* D outorando em Ciências Sociais pela U niversidade Estadual de Campinas-U NICAM P, na área de trabalho e sindicalismo. Tem artigos publicados nas áreas de política e trabalho. É autor do livro $\mathrm{Na}$ trama da história - $\mathrm{O}$ movimento operário de Sergipe (2000).
} 
Se os avanços positivos são enormes, o fosso social também o é. Apesar de toda a tecnologia, é sabido que faltam água, educação, saúde e trabalho para amplos setores da humanidade. $\mathrm{O}$ sentido de $\mathrm{N}$ ação cada dia mais representa menos, o que já foi um dia. O s Estados nacionais perdem a capacidade de decidir soberanamente os seus rumos.

As possibilidades são muitas, e perpassam todos os setores em que se dá a reprodução social (D owbor, 1999). A microeletrônica, a robótica e a informática associadas às novas formas de administrar o trabalho permitem grandes transformações no mundo da produção e fazem surgir novos signos explicativos: III revolução industrial, toytotismo, especialização flexível, reestruturação produtiva.

São muitas as correntes de análise: para alguns a categoria trabalho perdeu centralidade (Gortz, 1980); existem os que enxergam nesse processo em curso o fim da alienação do trabalho (Sabel e Piore, 1984); fim do emprego (Rifkin, 1995); outros negam o advento da sociedade pósindustrial dominada pelo setor de serviços (Kurz, 1982); há ainda correntes que continuam advogando a centralidade do trabalho, não concordando com a tese do fim da classe-que-vive-do-trabalho (Antunes, 1997).

Dentro desses modelos analíticos, existem linhas interpretativas defendendo a existência de um duplo mundo do trabalho, resultado desse processo de terceirização, toyotização e flexibilização, com parte da classe trabalhadora relativamente intelectualizada, polivalente e multifuncional e outra parte, sob condições extremamente precárias, sem qualificação (Antunes, 1999).

Dentro dessa última linha analítica, há interpretações que adotam denominações do tipo: elite ou privilegiados, como definidoras dos trabaIhadores tidos como estáveis. Estes surgem em função do processo de terceirização que exige, também, uma maior qualificação de seus trabalhadores ao criar uma elite [sem grifo no original], de trabalhadores altamente especializada (W awrzyniak, 1999). 
O s trabalhadores que permanecem empregad os nas grandes empresas - os trabalhadores ainda fordistas - tendem a constituir uma 'elite' [sem grifo no original], isto é um pequeno contingente, em geral bem qualificado, que continua sendo assalariado e protegido pela legislação trabaIhista (Druck, 1999).

Como reverso da moeda, restam os trabalhadores que são demitidos, perdendo o caráter de estáveis, o estatuto de fordistas e, trabalhando

em geral, desprovidos de uma série de direitos, nem sempre com a cobertura da legislação trabalhista, com salários menores, menor qualificação, instáveis, muitos sem carteira de trabalho assinada; constituem uma categoria inferior (Druck, 1999).

Estes formariam o time dosinstáveis, dos desclassificados.

São muitas as interpretações do processo em curso sobre o mundo do trabalho. Essa diversidade de análises nos levou a fazer um estudo-decaso com os trabalhadores da Fafen/Petrobrás em Sergipe, no afã de entender até que ponto são precisas essas leituras e quais as que teriam maior capacidade de explicação do processo.

Ao escolhermos para estudo de caso a Fafen/Petrobrás, temos claro que a mesma se insere dentro do Setor Produtivo Estatal (SPE) possuindo, portanto características particulares inerentes a esse setor ${ }^{1}$. Este fato, apesar de limitar nossa capacidade de generalização, não impede que os movimentos aí detectados sirvam como instrumentos analíticos, a partir dos quais possamos construir inferências que digam respeito ao mundo do trabalho no nosso país.

1 Alveal identifica que após a Grande D epressão cresce de forma marcante a presença do Estado na Economia. Este movimento ao tempo que é internacional se notabiliza no papel econômico-político do Setor Produtivo Estatal (SPE). A autora, ao tempo que chama atenção para os aspectos particulares desse setor em relação aos setores privados nacionais ou internacionais, identifica também as características próp rias que possuem cada ator dentro do próprio SPE. Ao tempo que possuem unidades pelo duplo papel desempenhado na relação junto ao Estado e ao mercado, esses atores são portadores também de características próprias, de acordo com a dinâmica de interação que desenvolvem ao se inserirem na economia (Alveal, 1994). 
Metodologia

Levantamos os dados através de pesquisa qualitativa, entrevistas semiestruturadas com operários, engenheiros, dirigentes e ex-dirigentes sindicais, realizadas entre os meses de fevereiro e maio do ano 2000. Utilizamos boletins do sindicato e relatórios da empresa. O uvimos 27 trabalhadores na fábrica de Laranjeiras - SE. Afora a engenharia, sempre ouvimos dois por setor, e faríamos triangulação se fosse necessário. Encerramos as entrevistas quando se tornaram repetitivas.

\section{A fábrica}

A Fafen/Petrobrás/Se começou a produzir em Sergipe em 1982. O riginariamente chamava-se Nitrofértil, com duas fábricas, uma no pólo petroquímico de Camaçari na Bahia, e outra na cidade de Laranjeiras em Sergipe. Compunha o setor estatal de fertilizante, formado por 7 empresas controladas pela Petrofértil, subsidiária da Petrobrás. 0 presidente Fernando Collor privatizou todas as empresas do setor, restando apenas a N itrofértil, que em 1993, a partir de um decreto do então Presidente Itamar Franco, foi incorporada diretamente à Petrobrás, passando a chamar-se FAFEN e permanecendo com as duas fábricas.

A Fafen em Sergipe, como indústria petroquímica, fabrica seus produtos a partir de complicadas reações físico-químicas. Processando continuamente gás natural, produz amônia e uréia, como produtos principais, e gás carbônico como subproduto.

0 controle do processo de fabricação consiste em manter, sob rígidos valores, as variáveis: pressão, temperatura e vazão dos diversos fluxos. A fábrica trabalha sob condições extremamente severas, com temperaturas atingindo valores de $1.200{ }^{\circ} \mathrm{C}$, e pressões que alcançam mais de $250 \mathrm{~kg} / \mathrm{cm}^{2}$, cujo descontrole põe em risco a vida dos operários e os equipamentos. Alguns fluidos envolvidos no processamento são tóxicos, inflamáveis e explosivos. 
A fábrica opera 24 horas por dia. O s operadores que controlam 0 processo trabalham em regime de turnos de revezamentos. O peram as unidades a partir de parâmetros previamente estabelecidos, acompanhando-os diuturnamente, visando manter estável a unidade. Este controle significa atuar de forma preventiva e contínua, evitando o descontrole do processamento e, quando o mesmo acontece, cabe à equipe de operação controlá-lo.

Esse tipo de controle evita o surgimento de anormalidades e envolve também o setor de manutenção que, ao atuar preventivamente sobre os equipamentos e/ou instrumentos, evita que os mesmos dêem problemas, e atua corretivamente quando esses se danificam. Em função da periculosidade, responsabilidade e complexidade exigidas, a mão-de-obra requerida nesse tipo de fábrica tem um alto grau de especialização, sendo necessários vários anos para se preparar um operário.

\section{A década de 80}

0 movimento sindical no Brasil foi sufocado pelo golpe militar de 64 (Rodrigues, 1999). Em Sergipe, até meados dos anos 80, eram os estudantes da Universidade Federal que davam a tônica dos movimentos. Esta realidade perdurou até a construção do novo sindicalismo (Blass, 1999; M angabeira, 1993; Santana, 1999) no Estado, na década de 80. Pari passu com a fundação da CUT estadual, foram criados pelos ativistas ligados, majoritariamente, ao Partido dos Trabalhadores e alguns poucos, ligados ao PC do B e PCB, diversos sindicatos de trabalhadores urbanose rurais, e outros sindicatos que já existiam foram conquistados dos pelegos.

No final dos anos 80 e início dos anos 90, praticamente todas as categorias já contavam com seus sindicatos, e muitas delas já haviam realizado grandes paralisações. N essa fase, as organizações cutistas ajudaram com pessoal, material de propaganda e cursos de formação. 


\section{O Sindiquímica}

As ações do sindicato dos trabalhadores químicose petroquímicos de Sergipe - Sindiquímica - foram fundamentais à construção do novo sindicalismo em Sergipe. Ele surgiu inicialmente como associação (APEQ), em 1982. Em 1985 ganhou a carta sindical e, em 1995 se fundiu com 0 Sindipetro Alagoas/Sergipe. 0 Sindiquímica, apesar da abrangência do seu estatuto, na prática, contava mesmo era com os 470 trabalhadores que, na década de oitenta, formavam o efetivo da Fafen².

No seu fazer sindical, os dirigentes dessa entidade inovaram pelo uso de: carros de som, computador, cursos de formação, devolução do imposto sindical, reformulação de estatuto, criação do fundo de greve, sede socializada, presenças mútuas nos atos, inclusive fora do Estado. Todas estas ações, associadas ao forte discurso classista, ao tempo que mobilizaram os trabalhadores, possibilitaram aos dirigentes do Sindiquímica e sua corrente política a hegemonia ${ }^{3}$ do movimento no Estado.

0 apoio dos trabalhadores da Fafen ao seu sindicato resultava não só de todos os aspectos anteriormente relatados, mas também das muitas vitórias alcançadas. A cada campanha salarial, direitos eram conquistados: hora extra a 100\%; direito de folgar a jornada seguinte após dobra de turno por interesse da empresa, com intervalo menor do que 11 horas; caso retornasse, ganhava 16 horas a 100\%; 5 folgas sem desconto por ano e mais uma com desconto sem outras conseqüências; promoção por mérito a cada 12, 18 ou 24 meses, dependendo de avaliação funcional; direito a 7 dias de folga por ano para os trabalhadores que participassem da brigada de incêndio e que, num período de um ano, não faltassem a nenhum dos treinamentos; participação com 1/3 da contribuição total, na manutenção do fundo de previdência privada - PETRO S; prêmio de férias

2 Apesar de só em 1993 a N itrofértil passar a ser chamada de Fafen, após a incorporação à Petrobrás, nós iremos, por motivos didáticos, nos referir a Fafen em todo o período. Da mesma forma, quando citamos Fafen estamos referindo-nos à planta de Sergipe, apesar da existência de outra planta na Bahia.

3 São egressos da Fafen todos os presidentes da CUT-Sergipe, desde a fundação. 
de $100 \%$ sobre o salário-base, para os que não tivessem faltas no período; assistência médica supletiva; tabela salarial idêntica à da Petrobrás (as empresas, mesmo que coligadas, controladas ou subsidiárias, não tinham tabela igual, sendo normalmente inferiores); gatilho salarial; promoção através de concurso interno; presença dos trabalhadores nas comissões de transporte e alimentação da empresa; recebimento garantido das horas extras; respeito aos direitos trabalhistas; impedimento de demissões em massa. Estes foram alguns dos direitos conquistad os direta ou indiretamente, no decorrer da década de 80 e início de 90.

Era muito forte o sentimento que a categoria possuía sobre a sua força e seu poder de fazer a empresa respeitá-los... antes o sindicato ditava as normas, 0 ambiente aqui em baixo era melhor, pois na balança, 0 sindicato pesava mais na relação com a empresa. Hoje a força do sindicato está muito menor... (operador). Isso se materializava nas conquistas citadas anteriormente e na capacidade de fazer valer os seus direitos: mesmo aqueles engenheiros ou encarregad os mais truculentos eram obrigados a recuar frente à força da categoria, que teve organização suficiente para reverter diversas punições. Quando do final do processo de privatização do setor de fertilizantes, a Fafen não tinha nenhum demitido, todos já haviam sido reintegrados, dirigentes sindicais ou não. 0 nível de organização e de ousadia era tamanho que no ano de 1993, no auge do processo de privatização, os trabalhadores puxados pelo sindicato, impediram que a empresa Price W estinghouse entrasse na Fafen para avaliá-la.

\section{A década de 90}

As conquistas da categoria sofreram um revés a partir do governo Collor e da implementação da sua política neoliberal/privatista. Collor, a partir do álibi de caça aos marajás, elege os trabalhadores, suas conquistas e seus salários, como vilões da crise do país, criando um clima propício ao arrocho salarial, à desregulamentação de direitos trabalhistas, e à privatização das estatais (Romão, 1992). 
Associando esta política ao processo de abertura comercial (Boito, 1999), o então Presidente permitiu concorrência extremamente predatória às empresas nacionais. Estas, como forma de se defender, passam a fazer suas reestruturações (Lima e Araújo, 1999) através da incorporação, ou não, dos avanços permitidos pela microeletrônica e pela informática, resultando em demissões em massa (Mattoso, 1999).

Com Itamar Franco, a política neoliberal caminhou a passos mais lentos, e só depois de Fernando Henrique assumir a Presidência da República, é que a política de desindustrialização (Pochmann, 2000) e desregulamentação de direitos ganhou rapidez e dimensões bem maiores do que aquelas vistas anteriormente. Como resultado, surgiram dados alarmantes de desemprego e desrespeito à legislação trabalhista, com crescimento da exclusão social (D upas, 1999).

Resultante dessas reestruturações, as estatais que eram paradigma positivo, em alguns casos, puxando as negociações para cima, a exemplo do setor bancário (Araújo, et al. 1999), passaram a ser vistas como privilegiadas, favorecendo o endurecimento das empresas nas negociações.

Se para os petroquímicos de Sergipe, a década de 80 não foi uma década perdida, o mesmo não pode ser dito em relação aos anos 90 . Nestes anos, a Fafen teve que se adequar às políticas neoliberais. A palavra de ordem passou a ser enxugamento, traduzida em inúmeras reduções: de despesas com manutenção; de estoques; da folha de pagamento, seja arrochando salário ou reduzindo pessoal, através dos PDV's e prêmios para aposentadorias. Efetuaram-se cortes: no transporte e na alimentação; na assistência médica supletiva; na previdência privada. Extinguiram-se atividades, cancelaram-se as ausências abonadas e diminuíram-se os níveis hierárquicos.

A toda essas ações somava-se o discurso diuturno das gerências sobre a necessidade de redução de pessoal. Muitas eram as reuniões, gráficos e dados explicativos. Estava instalado o terrorismo psicológico. Notícias atingem os trabalhadores de frente: ...empresa y demitiu tantos, .... a fábrica $x$ foi 
privatizada, ... férias coletivas, .... governo exigiu $10 \%$ de corte com pessoa; ...0 leste desmoronou... Representam golpes na sua subjetividade. O soperários que, na década anterior, aprenderam a ser portadores de força e que as estavam acumulando para transformar a sociedade, .... sindicato tinha um sonho de transformar a realidade, construindo uma sociedade igualitária..., (operador) começam a se sentir incapazes na nova realidade.

\section{A reestruturação da fábrica}

Em meados dos anos 80, a Fafen introduz novas formas de administrar o trabalho, baseadas na modernidade japonesa. O s primeiros foram: Balanço Social e CCQ . O BS consistia em conhecer, através de questionário, as opiniões e anseios dos empregados sobre temas relacionados à fábrica. De posse dos dados, a empresa executava mudanças, que atribuía à vontade da maioria. Alguns trabalhadores eram escolhidos para fazer parte da comissão de balanço social e a partir daí, muitos incorporavam o discurso da empresa e tentavam influenciar os demais.

O BS normalmente acontecia próximo à campanha salarial. Era uma forma de esfriar os ânimos dos trabalhadores. Tática logo percebida pelo sindicato, que desde cedo passou a combatê-la. 0 enfrentamento do sindicato e a suas próprias limitações, esvaziaram o BS.

O Círculo de Controle de Qualidade - CCQ surge após o BS ter-se esvaído, no final dos anos 80 . Tem conotação claramente econômica. A tese é que peão, chefe e engenheiro devem juntar-se sem distinções, formando os grupos de controle de qualidade para fazer a empresa produzir mais.

Como seu antecessor, tem no início, aspectos interessantes para o peão ....Na época do CCQ surgiram idéias novas para a empresa, o clima era bom... (operador). O sengenheirose chefes normalmente distantes dos mesmos, agora comportavam-se mais cordialmente, sentavam com ele em pé de igualdade para discutir o que, onde e como melhorar, economizare 
produzir mais. 0 ápice do CCQ era a apresentação dos trabalhos produzidos pelos grupos, feita normalmente pelo pessoal de nível médio, no auditório, na presença da direção. As melhores idéias recebiam prêmios, nunca em dinheiro. Inicialmente os trabalhadores incorporaram-se a ele, formando diversos grupos, mesmo com a dura oposição do sindicato.

Logo, os trabalhadores, fustigados pelo sindicato, passaram também a questioná-lo: queriam receber os prêmios em dinheiro... Se fazia a empresar ganhar mais, por que não ganhar mais também? (administrativo). M ais uma vez, as cobranças esvaziaram o programa, que foi também deixado de mão. .... CCQ , balanço social é oba oba, e o tiro saiu pela culatra, esses projetos só funcionam onde o peão não tem esclarecimento, onde ele é preparado não dá certo, só criou um fosso. Tanto é que acabou... (engenheiro).

Apesar da vida curta, o BS e o CCQ simbolizaram uma mudança de posição da empresa, ao buscar legitimar seus métodos de controle. Demonstração clara do interesse de disputar com o sindicato o controle político do processo produtivo.

Com a crise dos anos 90 sobre o mercado de trabalho (Mattoso, 1999), com demissões e perdas de direitos levados a efeito pela política neoliberal, surgia mais espaço para implantação de novos programas atingindo o operário na sua subjetividade. Apesar de o sindicato continuar com discurso classista, a base já não o acompanhava como antes, começaram a rarear os movimentos, os galos cegos perderam força, e as assembléias esvaziaram-se. 0 sindicato não tem o apoio que tinha antes.. (eletricista); ...0 sindicato tá muito fraco, a situação não é favorável, .... desemprego, ... hoje não se tem opção de mudar de emprego... (caldeireiro).

Percebendo esta realidade, a empresa avançou na reestruturação, impondo mudanças, sem discutir com o sindicato. Acabou com os concursos internos, ...hoje quem tem qualidade não tem vez. Só aparece quem a chefia quer, tem que servir a ela. 0 concursado tem diferença, a equipe confia mais no supervisor, tem mais segurança (operador). Transformou em cargo de confiança funções que tinham voz de comando entre a peãozada 
(encarregados, operadores III), reorganizou fisicamente as salas, tentando isolar os chefes de grupo dos demais ...0 aquário ${ }^{4}$ é para evitar um maior diálogo... (operador). Reduziu os níveis hierárquicos, diminuindo 0 encarreiramento das diversas funções ...Agora não se tem carreira não se sabe para onde vai.. (eletricista). Retirou do acordo coletivo as proteções contra demissões. Reduziu os efetivos mínimos. Estas ações reduziram custos e aumentaram o controle sobre os trabalhadores.

O s encarregados e 0 peradores III passam a ser indicados recebendo gratificação de chefia. Perdem a estabilidade da função, ...não mais existe chefe de grupo, o chefe está, ... e empresa manipula ao bel prazer, joga como quer, hoje o chefe vive na corda bamba, errou perde a chefia... (operador). Isso tornou os novos supervisores meros cumpridores de determinações. No caso dos operadores, os supervisores (operadores II), antigos operadores III, que deixaram de existir, ganharam o direito de ter um carro pequeno pegando-o na porta. Não usam mais o ônibus de turno, portanto, não ficam sujeitos às cobranças nem participam mais das assembléias na porta da fábrica. Foram mudanças fundamentais para os interesses da empresa. Os supervisores possuem grande conhecimento técnico e comandam as equipes que controlam a produção. Sem este pessoal, fica enfraquecida, sobremaneira, qualquer ação do sindicato. Segundo depoimento de um ex-dirigente sindical, foi a presença desses supervisores na fundação do sindicato que muito o fortaleceu: 0 sindicato surgiu com quem tinha poder de mando, é por isso que ele tinha força.

No setor administrativo, funções como telegrafista, telefonistas e teletipista foram extintas. Setores estão sendo enxugados ou estão tendo suas atividades centralizadas em outros locais. M uitas são as aposentadorias proporcionais, as pessoas são relocadas, transferidas, assumem novas funções. Alguns são transferidos, substituindo operadores ...o cara era do laboratório, aí depois de 10, 15 anos, passa para operação, esse cara não 
tem malícia, pode se acidentar e acidentar os outros, ...caldeireiro vira rapidamente instrumentista... (instrumentista). A sensação é de impotência, todos temem pelo futuro, o discurso da necessidade de economia continua. A instabilidade é constante. Isso tem um enorme efeito desmobilizador, as pessoas sentem-se descartáveis. Esse sentimento cresceu com a implantação da ISO 9000.

A implantação da ISO 9000 na Fafen iniciou-se em 1992 ...Em 15 de março de 96 foram certificados os processos de produção e comercialização. Para isso diversos ajustes tiveram que ser feitos, [...] Em 1999 foram recertificados.. (engenheiro). A maioria dos trabalhadores pesquisados percebe que a certificação significou alguns ganhos, ..serve para treinar meIhor e se aprimorar.. (operador), mas muito aquém do propagado. No fundamental, a maioria concorda que tem muito de ...é mais marketing (mecânico). ...A ISO é só burocracia, se prepara tudo para ganhar, mais depois... o que melhora é limpeza, a documentação. Mas depois...os procedimentos são largados, depois que passa a auditoria tudo é largado. É só pra ganhar o certificado... (eletricista). Para eles, na Fafen ...os procedimentosjá eram feitos com fichas e anotações desde a época de.. (instrumentista).

A opinião praticamente unânime entre os pesquisados, é de que ...Não teve automação, melhorias ocorreram [...], aumentou-se as capacidades, tem projeto para automação mais nunca sai.. (engenheiro). As reduções que houve e a economia feita, ocorreram pelos cortes efetuados. No tocante à automação, está nos mesmos níveis de 1982. As mudanças foram basicamente de caráter organizacional.

A área operacional da Fafen era composta inicialmente por 4 setores: setor de amônia, setor de uréia, setor de movimentação e setor de utilidades. Foram reduzidos para 2. A uréia absorveu a movimentação e a amônia incorporou a utilidades pari passu, reduziu-se o número mínimo de operadores de 112 para 60. Eles passaram a atuar em mais de uma área, na chamada polivalência, prejudicando o treinamento. Muitas vezes, 0 operador assume áreas sem o treinamento devido, com todos os riscos 
que isso possa trazer. É importante salientar que para se ter um operador razoavelmente capacitado leva-se no mínimo 5 anos.

Não obstante, a reestruturação ainda não foi concluída. Na campanha salarial de 1999 a Petrobrás conseguiu comprar o extraturno ${ }^{5}$, tentou e não conseguiu, comprar a quinta turma ${ }^{6}$; se o conseguisse, reduziria ainda mais o efetivo. É possível que em 2000 tente de novo. Na Fafen, o projeto é automatizar, unificando as salas de controle, reduzindo o número de operadores.

$\mathrm{Na}$ manutenção, a redução também é grande. Na década de 80 , se somarmos mecânicos, caldeireiros e os instrumentistas da própria empresa, entre técnicos, encarregados e ... peão puro e simples..., existia em torno de 92 trabalhadores. Hoje esse efetivo é de 41. Essa redução é agravada pelo envelhecimento da unidade, ...surgiram trabalhos que não haviam antes, como substituir válvulas, trocar trechos de tubulaçõese maior número de vazamentos... (caldeireiro).

Sem automação, a elevação de capacidade 7 ao longo desses 18 anos foi feita aproveitando-se as folgase introduzindo-se novos equipamentos. Como não houve acréscimo de trabalhadores terceirizados, proporcionalmente aos que saíram, restou sobrecarga para os que ficaram, muitos com limitações médicas ...quem fica, fica sobrecarregado, tudo sob tensão, qualquer coisa tá brigando... (eletricista); ....antes eram dois para cada tarefa, hoje saem os dois, mas como são muitas tarefas temos que nos separar... (instrumentista). É preciso adicionarmos ainda, o envelhecimento da equipe: se há ganho pelo lado da experiência, os quase 20 anos a mais pesam ao executar tarefas, principalmente quando em ambientes com temperaturas de 40 a $60^{\circ} \mathrm{C}$, ou ao exigir força para subir por escadas de marinheiro, em torres de até $70 \mathrm{~m}$ de altura. O s projetos, no entanto, falam em aumentar a terceirização.

5 Como foram indenizados, os trabalhadores de turno não mais receberam hora extra quando trabalhassem em feriados, à exceção do Natal e Ano Novo.

6 Após a Constituinte de 88 os trabalhadores de turno conquistaram o direito de trabalhar 6 horas. Em muitos locais, a

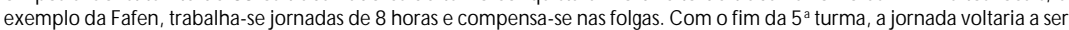
de 8 horas sem compensação.

7 A produção de projeto era 907 ton/dia de amônia e 1.100 ton/dia de uréia. Com alguns ajustes, elevou-se a produção para 1.100 ton/dia de amônia e 1450 ton/dia de uréia. Em 1998 foi feito o Revamp das unidades, e a produção passou a 1.230 ton/dia de amônia e 1.870 ton/dia de uréia. 
A segurança industrial também se reestruturou. Responsável direta na década passada pelas questões de segurança. Acompanhar, fiscalizar as manutenções e cumprimento das normas, dar cursos e manter em bom estado os equipamentos de segurança eram algumas das tarefas deste pessoal. Trabalhavam em turnos, em apoio à operação e à manutenção. Esta última também mantinha pessoal no turno. As novas metodologias retiraram do turno o pessoal de segurança e manutenção.

Suprimiram os cuidados que antes cabiam à segurança, ..Passamosa fazer nossa própria segurança devido à empresa tirar os orientadores, ...é até interessante, ... mas o povo da segurança hoje é só burocracia... (eletricista). Isso significou transferência de responsabilidade. 0 setor especializou-se em estatísticas e gráficos.

A brigada de incêndio foi reformulada, houve resistência dos trabaIhadores, ocasionando um bom período sem treinamento. Hoje, os pesquisados reconhecem que ela não tem a mesma eficácia. A meta acidente zero virou arma contra os trabalhadores, que agora se vêem obrigados a trabalhar doentes...metas precisam ser cumpridas... sem absenteísmo, sem afastamentos... (operador). N a verdade ficam nas salas sem fazer nada, mas não podem ficar em casa, ... Todo mundo tá ficando com medo, vem trabalhar doente, ...tá ficando com medo (operador).

0 risco desta atitude, entre outros, é o de mascarar a relação direta que existe entre os incidentes, acidentes sem e com gravidade, nesta ordem. Para cada $x$ número dos primeiros, ocorreram um $(x-1)$ número dos posteriores e assim sucessivamente. Logo, se não existir uma política de prevenção, aumenta a possibilidade de acidentes graves. Este raciocínio pode ser aplicado aos acidentes operacionais. Não se evitando os pequenos, acontecerão os grandes, à semelhança daqueles ocorridos na baía da Guanabara, rio Iguaçu e rio Barigui. A reestruturação neste setor também não está concluída. Recentemente, o terceirizado que fazia o acompanhamento dos EPI's foi retirado. Até o momento da pesquisa, a tarefa estava sem ser executada, estando os equipamentos necessários nas emergências, sem o devido acompanhamento. 
No setor de saúde ocupacional, antes havia 5 técnicos em enfermagem do trabalho de turno, 1 por grupo. Tecnicamente capazes, conheciam as limitações e necessidades dos trabalhadores de seu grupo, aspecto importante em caso de acidente. À medida que se foram aposentando, o serviço foi sendo terceirizado. Hoje todas as enfermeiras de turno são terceirizadas.

As primeiras enfermeiras terceirizadas tinham que ser especialistas em enfermagem do trabalho, recebiam plano de saúde e trabalhavam na mesma escala dos trabalhadores de turno da Fafen. Em seguida, o contrato da empreiteira foi refeito. Com esse novo contrato, passaram a ganhar praticamente metade do que ganhavam antes. É bom frisar que, quando elas entraram, já ganhavam metade do que ganhavam as técnicas da Fafen. $\mathrm{Não}$ há mais direito a plano de saúde, trabalham em escala de 24 horas ininterruptas, e não é mais exigido o curso de especialização em enfermagem do trabalho, implicando uma menor qualificação do quadro e descrédito no serviço, .. estamos com enfermeiras que não estão ligados a nossa área... (operador), ....as novas enfermeiras não têm a mesma condição... (mecânico).

Ainda restam um médico e 3 técnicos de enfermagem do trabalho. O s projetos são: aposentar o médico sem substituí-lo, ou terceirizar. Com os técnicos, a idéia é aposentar e transferir.

No setor de segurança patrimonial, os vigilantes vivem drama parecido. Além da redução, não mais estão lotados na Fafen, foram centralizados em outro órgão. Em 1999, trabalharam quase o ano todo, lado-a-lado com vigilantes de empreiteira. Como está havendo reformulações por toda a Petrobrás, foram trazidos vigilantes de outras áreas e retirados os de empreiteira. A meta é terceirizar todo o serviço.

No laboratório, o efetivo era inicialmente de 4 analistas por turno, somando um total de 16 , foram reduzidos para 3, em seguida para 2, e hoje resta apenas 1 por turno. ..A redução de pessoal foi mais por conta da 
retirada de análises do que pelos instrumentos novos... (analista); ... Retiraram as análises que demandavam mais tempo... (analista).

Apesar da ISO, as condições de trabalho são inferiores, a manutenção preditiva acabou, ... acabou a manutenção preventiva e aumentaram as corretivas, já teve uma época que só tinha preventiva, hoje é só corretiva e tem que fazer as pressas, só muda e faz preventiva quando é preventiva da ISO 9000... (instrumentista). Pela carência de pessoal e de peça de reposição é comum vermos equipamentos, que originalmente deveriam ficar revisados e de stand by, permanecerem quebrados.

Esta reestruturação reflete tecnicamente na empresa. A redução de pessoal, a diminuição de peças de reposição e a economia com manutenção

...Foram feitas de uma forma maluca, desorganizada e deu problema... Tem peças que não existem na prateleira, o fabricante só entrega com 9 meses, se elas quebrarem não podem ser recuperadas, nesses casos, mesmo sendo caras é preciso ter estoque ou do contrário corre o risco de ficar parado 9 meses. No início, eles não respeitaram isso, e tentaram segurar, mas depois veio ordem de cima para voltar atrás (engenheiro).

A precarização das condições de trabalho e segurança deverá ter seus reflexos, tanto no tocante à eficiência e produtividade operacional, quanto na própria segurança, sendo previsível um maior número de acidentes, caso permaneça a atual política.

Não bastassem os reflexos técnicos, existem as repercussões sociais e políticas. O soperários que anteriormente acumularam vitórias, aprendendo que a origem da sua força era a necessidade que a empresa tinha deles, vêem-se hoje enormemente fragilizados. Seja pelo discurso de redução de quadro, seja pela mudança nos padrões de manutenção, treinamento e acompanhamento operacional. Sentem-se dispensáveis, ...M e sinto menos seguro, me sinto como um verme, jogado pra trabalhar sem valor nenhum, só dão valor na hora que estão no sufoco, ...quebrou e vai parar, ....na hora do trabaIho, ... quando estão a 105\% eles esquecem... (mecânico). 
O clima de instabilidade é geral, ...Antes a estabilidade existia. Hoje as privatizações deixam tudo mais perigoso, além do que o sindicato ficou com menosforça... (operador).

As regras eram claras,

...fez hora extra, recebe. Hoje nada é garantido, pode receber ou não... (eletricista); ....as vezes dizem que paga e paga, outras vezes dizem que paga e não paga, e fica por isso mesmo, tudo dependendo da vontade do chefe.. (mecânico); As promoçõeseram mais transparentes, tinha tempo certo, os encarregados avaliavam e passavam para 0 chefe do setor, hoje tudo fica mais restrito ao chefe do setor... (caldeireiro).

0 autoritarismo nas relações de trabalho recrudesceu ...Até aquelesengenheiros que eram manso, hoje tão violento, falando grosso... (instrumentista). $\mathrm{E}$ continua o processo de desagregação do coletivo (Laranjeiras, 1998), sob formas novas, a exemplo da política de concessão de bônus implantada no ano 2000, sobre a qual, os trabalhadores e o sindicato não têm nenhum controle.

\section{Considerações finais}

A pesquisa indica que o processo de reestruturação da Fafen/Petrobrás/ Se resultou fundamentalmente de mudanças organizacionais, com muito pouca automação. Mesmo a terceirização foi bem inferior à redução do quadro próprio.

A certificação das unidades foi realizada concomitantemente à política de redução de custos. Isso, ao tempo que levou à precarização das condições de trabalho, não significou grandes mudanças, como comumente propagado pelos certificadores, permitindo relativizar os seus resultados.

É possível afirmar também que os trabalhadores pesquisados convivem com uma situação clara de instabilidade, de perda de direitos, de conquistas, de condições de trabalho e segurança. 
Identificou-se que os trabalhadores da Fafen/Petrobrás têm sua subjetividade atingida, o que concorre para o grau de apatia registrado no enfretamento dos problemas.

Ficou patente a incapacidade do sindicato da categoria em organizar os trabalhadores frente à nova realidade, apesar da sua anterior ligação com a base, de sua experiência e do discurso classista.

Conclui-se que o processo de precarização, retirada de direitos e deterioração das condições de trabalho permanece em andamento, tratase de um processo em curso. Realidade inclusive, que não diz respeito apenas à Fafen/Petrobrás. Pesquisas apontam avanços da terceirização (Araújo, et al. 1999), demissões que devem continuar ocorrendo (Banco Central, FSP, 2000), e existência de projetos no Congresso N acional que visam desregulamentar o mercado de trabalho e tendem a ...prejudicar mesmo os sindicatos mais atuantes... (N eto e N eves, 1999).

Apesar das disparidades registradas entre os trabalhadores terceirizados e os da Petrobrás, ficou patente que a instabilidade é uma realidade que atinge os dois.

Finalmente, os dados levantados permitem concluir que são imprecisas as análises que concluem pela existência de trabalhadores de elite, estáveis, privilegiados em detrimento de outros que seriam osinstáveis, os desclassificados. Adentrando o mundo dos signos, ícones e metáforas, percebemos que os mesmos são construções que introjetam conteúdos, valorações. No caso específico, elite e estável, são símbolos que muito distam daqueles que perdem direitos e se precarizam dia-a-dia.

Ao contrário, a pesquisa indica não existir trabalhador estável, muito menos elite, mesmo os que atualmente estão empregados em empresas como a Petrobrás, têm hoje menos estabilidade, condições de trabalho, de saúde, e segurança do que tinham ontem e, pelas perspectivas, menos do que terão amanhã. Portanto, nada que configure a estabilidade.

Essas afirmações têm o caráter de tendências, tem-se claro que se trata de processo em curso, algo inconcluso, suscetível a mudanças. E como tal, o ontem nós vimos, o hoje estamos analisando, o amanhã está a depender da capacidade dos próprios trabalhadores, de deterem ou não essa maré de precarização, que tem ceifado direitos e garantias, e empurrado 0 conjunto da classe trabalhadora à barbárie. 


\section{Referências bibliográficas}

CONTRERAS, Alveal, DEL CARMEN, Edelmira. O s desbravadores: a Petrobrás e a construção do Brasil industrial. Rio de Janeiro: ANPO CS/Relume Dumará, 1994.

ANTUNES, Ricardo. Adeus ao trabalho?: ensaio sobre as metamorfoses e a centralidade do mundo do trabalho. São Paulo, Cortez Editora, 1997.

. O s sentidos do trabalho. São Paulo: Editora Boitempo, 1999.

ARAUJO . Angela M. Carneiro; CARTO NI, Daniela M.; JUSTO, Carolina R. D. M ello. Reestruturação produtiva e negociação coletiva: a experiência recente dos metalúrgicos, dos químicos e dos bancários de Campinas. Caxambu: trabalho apresentado no XXIII encontro anual da ANPOCS, 1999.

BLASS, Leila M . da Silva. Novo sindicalismo: persistência e descontinuidade. In: I.J. Rodrigues (org.). 0 novo sindicalismo vinte anos depois. Petropólis: Educ/Vozes/ Unitrabalho, 1999.

BO ITO, Armando. Política neoliberal e sindicalismo no Brasil. São Paulo: Editora Xamã, 1999.

DAW O BO R, Ladislau. A reprodução social. Petrópolis: Editora Vozes, 1999.

DRUCK, Maria Graça. Terceirização: (Des)fordizando a fábrica - um estudo do complexo petroquímico da Bahia. São Paulo: Boitempo, 1999.

DUPAS, Gilberto. Globalização, exclusão social e governabilidade. Recife: trabalho apresentado na I conferência latino americana e caribenha de ciências sociais, 1999.

GORZ, Andre. Adeus ao proletariado: para além do socialismo. 2a . Edição. Rio de Janeiro: Forense Universitária, 1987.

IAN NI, O ctavio. Teorias da globalização. Rio de Janeiro: Editora Civilização Brasileira, 1999.

KHUN, Thomas. A Estrutura das revoluções científicas. São Paulo: Perspectivas, 1994.

KURZ, Robert. O colapso da modernização. Tradução de Karen Elsabe Barbosa. São Paulo: Paz e Terra, 1982. 
LARANJEIRAS, Sônia. Há Lugar para o sindicalismo na sociedade pós-industrial? São Paulo em perspectiva, v.12, n. 1, 1998.

LIMA, Jacob C., ARAUJO, Neyara. Para além do 'novo sindicalismo': A crise do 'assalariamento' e as experiências com 'trabalho associado'. In: I.J. Rodrigues (org.). 0 novo sindicalismo vinte anos depois. Petropólis: Educ/Nozes/Unitrabalho, 1999.

MANGABEIRA. Wilma. Os dilemas do novo sindicalismo: Democracia e política em Volta Redonda. Rio de Janeiro: AN PO CS/Relume/D umará, 1993.

MATTOSO, Jorge. O Brasil desempregado. São Paulo: Editora Fundação Perseu Abramo, 1999.

NETO , Antonio Carvalho \& NEVES, M agda de Almeida. As respostas do sindicalismo mineiro aos desafios dos anos 90: Emprego, qualificação e remuneração variável. Caxambu: trabalho apresentado no XXIII encontro anual da ANPOCS, 1999.

PO CHEM AN N, Marcio. A mundialização das economias e os desafios dos sindicatos. In: R.K.M. Carrion \& P.G.F.Vizentini (org.). Globalização, neoliberalismo, privatizações. Porto Alegre: Prefeitura de Porto Alegre/CEDESP/UFRGS, 1998.

RIFKIN, Jeremy. Fim dos empregos. São Paulo: Makron Books, 1995.

RO DRIGUES, Iram Jácome. A trajetória do novo sindicalismo. In: I.J. Rodrigues (org.). O novo sindicalismo vinte anos depois. Petropólis: Educ/Nozes/Unitrabalho, 1999.

SABEL, C \& PIORE, M. The second industrial divide. New York: Basic Books, 1984.

SANTANA, Marco Aurélio. Política e história em disputa: o 'novo sindicalismo' e a idéia da ruptura com o passado. In: I.J. Rodrigues (org.). 0 novo sindicalismo vinte anos depois. Petropólis: Educ/Vozes/Unitrabalho, 1999.

TAVARES, Maria da Conceição. (Des)ajuste global e modernização conservadora. Rio de Janeiro: Paz e Terra, 1996.

W AWRZYNIAK, Sônia Isabel. O s vigilantes e as transformações no mundo do trabalho. Caxambu: trabalho apresentado no XXIII encontro anual da ANPO CS, 1999. 


\section{Resumo}

Esse trabalho busca contribuir para discussão da globalização e seus reflexos so bre os trabalhadores ditos estáveis, suas organizações, a subjetividade operária e o chão da fábrica a partir de Sergipe na década de 90 , no caso particular da Fábrica de Fertilizantes da Petrobrás (Fafen/Petrobrás). A tabulação e análise dos dados coletados, nos possibilita algumas conclusões: 1) As mudanças ocorridas no chão da fábrica denotam uma precarização das condições de trabalho externalizadas em: menos postos de serviço, mais tarefas, menos segurança, menos estabilidade, perda e flexibilização de direitos. Esse processo atinge diretamente os trabalhadores tidos como estáveis permitindo-nos concluir que não são precisas as afirmações que os denominam de "elite" ou privilegiados; 2) o sindicato da categoria, apesar da experiência dos seus quadros diretivos, que estavam à frente do movimento desde 0 início dos anos 80, tendo inclusive posição destacada a nível nacional, apesar do seu nível de organização e da sua inserção no interior da unidade fabril, foi incapaz de encontrar formas alternativas ao avanço da empresa, que consegue retirar muitas conquistas anteriores e cooptar antigas lideranças, criando um clima de impotência e atingindo diretamente a subjetividade da classe.

Palavras-chave: Globalização, sindicalismo, trabalhadores estáveis, precarização, petroleiros. 